\title{
THE INGARDENIAN DISTINCTION BETWEEN INSEPARABILITY AND DEPENDENCE: HISTORICAL AND SYSTEMATIC CONSIDERATIONS*
}

\section{MAREK PIWOWARCZYK}

DSc in Philosophy, Associate Professor.

Faculty of Philosophy, The John Paul II Catholic University of Lublin.

PL-20-950 Lublin, Poland.

E-mail: piwowar1@wp.pl

In this paper I present the Ingardenian distinction between inseparability and dependence. My considerations are both historical and systematic. The historical part of the paper accomplishes two goals. First, I show that in the Brentanian tradition the problem of existential (or broadly: ontological) conditioning was entangled into parts-whole theories. The best examples of such an approach are Kazimierz Twardowski's theory of the object and Edmund Husserl's theory of parts and wholes. Second, I exhibit the context within which Ingarden distinguished inseparability and dependence. Moreover, Ingarden's motivations are presented: the problem of understanding the Husserlian concept of "immanent transcendence," the issue of the existence of purely intentional objects, and finally the problem of the relationship between individual objects and ideas. The systematic part deals with the ambiguity of Ingarden's definition of inseparability. I seek to improve this definition by reference to the distinction (made by Ingarden himself) between absolute and summative wholes. I also present some divisions of inseparability and dependence and investigate whether these types of existential conditioning are reflexive, symmetric, or transitive.

Key words: inseparability, dependence, absolute whole, summative whole, Roman Ingarden, Edmund Husserl, Kazimierz Twardowski.

* This paper is a result of project no. $2017 / 27 / \mathrm{B} / \mathrm{HS} 1 / 02455$ and was funded by the National Science Center, Poland.

(C) MAREK PIWOWARCZYK, 2020 


\section{ИНГАРДЕНОВСКОЕ РАЗЛИЧЕНИЕ \\ НЕОТДЕЛИМОСТИ И ЗАВИСИМОСТИ: \\ ИСТОРИЧЕСКИЕ И СИСТЕМНЫЕ РАЗМЫШЛЕНИЯ}

\section{МАРЕК ПИВОВАРЧУК}

Доктор философских наук, доцент.

Факультет философии, Католический университет Люблина имени Иоанна Павла II.

PL-20-950 Люблин, Польша.

E-mail: piwowar1@wp.pl

В настоящей статье я собираюсь показать различение неотделимости и зависимости у Ингардена. Мои размышления носят как исторический, так и систематический характер. Историческая сторона статьи преследует двоякую цель: во-первых, я показываю, что в идущей от Брентано традиции проблема экзистенциальной (или, шире, онтологической) обусловленности была перенесена в теории о соотношении части и целого. Лучшими примерами подобного подхода выступают теория предметов Казимира Твардовского и учение Эдмунда Гуссерля о части и целом. Во-вторых, я освещаю тот контекст, в котором Ингарден провёл границу между неотделимостью и зависимостью. Кроме того, в статье показана мотивация Ингардена: проблема понимания Гуссерлевской концепции «имманентной трансценденции», проблема существования чисто интенциональных объектов и, наконец, проблема соотношения индивидуальных объектов и идей. Систематическая часть посвящена неоднозначности Ингарденовского определения неотделимости. Я предпринимаю попытку усовершенствовать это определение, ссылаясь на различие (сделанное самим Ингарденом) между абсолютной и суммарной целостностью. Я также привожу некоторые деления неотделимости и зависимости и исследую, являются ли эти типы экзистенциальной обусловленности рефлексивными, симметричными или транзитивными.

Ключевые слова: неотделимость, зависимость, абсолютная целостность, суммарная целостность, Роман Ингарден, Эдмунд Гуссерль, Казимир Твардовский.

\section{INTRODUCTION}

If one accepts Aristotelian substantialism, she usually is convinced that accidents are somehow conditioned in existence by their bearers: substances. If our Aristotelian scholar is also a theist, she maintains that created beings are existentially conditioned by God. But does she have in mind exactly the same type of existential conditioning? We intuitively feel that although accidents are distinct from their respective substance, they are not separate objects and they cannot be separated from their bearer. In contrast to this, created beings are separate from God although they cannot exist without God. This difference can be expressed accordingly in terms of inseparability and dependence, which was introduced by Roman Ingarden when developing his ontology. Accidents are inseparable from their substances but created beings are dependent on God.

In this paper I present the Ingardenian distinction between inseparability and dependence. This distinction is absent from contemporary analytical metaphysics al- 
though it seems to be very useful, particularly in the context of the problem of the inner structures of objects ${ }^{1}$.

My considerations are both historical and systematic. In the second section I show that in the Brentanian tradition the problem of existential (ontological) conditioning was entangled in parts-whole theories. The best examples of such an approach are Kazimierz Twardowski's theory of objects and Edmund Husserl's theory of parts and wholes. Section three exhibits the context within which Ingarden distinguished inseparability and dependence. Moreover, Ingarden's motivations are presented: a problem with understanding Husserlian "immanent transcendence," the issue of the existence of purely intentional objects, and the problem of the relationship between individual objects and ideas. Section four deals with the ambiguity of Ingarden's definition of inseparability. I improve upon this definition through reference to Ingarden's distinction between absolute and summative wholes. Finally, I present several divisions of inseparability and dependence and investigate whether these types of existential conditioning are reflexive, symmetric, or transitive.

At the beginning, however, a terminological remark is necessary. The term "inseparability” is my translation of „Unselbständigkeit“, „Unablösbarkeit“" , and the Polish term "niesamodzielność". The first of the German terms and the latter Polish one are sometimes translated as "non-self-sufficiency" (Szylewicz), "non-independence" (Findlay), or simply as "dependence" (Simons). Due to that fact that Ingarden wanted to emphasize that unselbständig entities can exist only within a whole, I think that the term "inseparability" is more suitable. "Separability" is my translation of „Selbständigkeit", „Ablösbarkeit", and "samodzielność" as well. "Dependence" stands for the German term „Abhängigkeit" and the Polish term "zależność". "Independence” is also my translation of „Unabhängigkeit" and "niezależność”. Adjectives corresponding to the above nouns are translated as "inseparable," "separable," dependent," and "independent"3.

\section{THE PROBLEM OF EXISTENTIAL CONDITIONING AS ENTANGLED IN THE PARTS-WHOLE THEORY: TWARDOWSKI AND HUSSERL}

In his most known book, On the Content and Object of Presentations, Kazimierz Twardowski not only explicates his work's title distinction but also builds a very original and sophisticated (for critics: intricate) theory of the object. An object is conceived

\footnotetext{
I tried to apply the Ingardenian distinction in this area. See Piwowarczyk (2019).

2 This translation of „Unablösbarkeit“ is made strictly in the context of Twardowski’s theory.

3 In accordance with these terminological decisions I have allowed myself to modify the English translations of some cited works.
} 
by him as a composed whole having different types of parts. Twardowski provides many divisions which distinguish such types of parts as: physical and metaphysical, material and formal (among the latter: primary and secondary), and parts of different ranks, orders, and degrees. For the purposes of this paper there is no need to analyze all these concepts. In lieu of this, I focus only on the distinction between the dependent (abhängig) and independent (unabhängig) parts of objects. Initially, Twardowski defines these parts in existential terms. Thus we have:

1. Independent parts "which can also exist by themselves, separated from the whole whose parts they are" (Twardowski, 1977, 48).

2. Unilaterally dependent parts "whose existence depends on others, while the existence of these other constituents does not depend on them" (Twardowski, 1977, 48-49).

3. Mutually dependent parts "which depend for their existence mutually on each other" (Twardowski, 1977, 49).

Twardowski elaborated his theory of the object as applicable to both existent and nonexistent objects. Therefore, the value of the presented division was limited and Twardowski sought to replace existential criterion with the criterion of conceivability. At the same time, he felt forced to admit that this new criterion was more suitable for the parts constituting the content of presentations (Twardowski, 1977, 49). In this context, Twardowski uses the words "separability" (Ablösbarkeit) and "inseparability” (Unablösbarkeit) and speaks of (Twardowski, 1977, 61):

1. Mutually separable parts: such parts, which can be conceived of without conceiving of other parts.

2. Mutually inseparable parts: such parts that can be distinguished but cannot be conceived of without each other.

3. Unilaterally separable parts: exemplified by parts A and B, such that A can be conceived of without B but B cannot be conceived of without A.

In this new division and in the previous one as well, Twardowski does not take into account the unilateral inseparability. Eugenia Ginsberg-Blaustein ${ }^{4}$ supposes that

4 Eugenia Ginsberg-Blaustein was born in 1905. After her studies at Lvov University under Kazimierz Twardowski she was a very active member of The Polish Philosophical Society. In 1928 Ginsberg-Blaustein studied in Berlin where she attended the lectures of Carl Stumpf, Max Wertheimer, Kurt Lewin, and Wolfgang Kohler. In 1930 she married Leopold Blaustein - a disciple of Kazimierz Twardowski, Kazimierz Ajdukiewicz, and Roman Ingarden. She was killed by Germans in 1942 (according to some sources in 1944) in Lvov. Her contribution to the phenomenological theory of dependence is analyzed in Żegleń (2018) and Magdziak (2016). On Leopold Blaustein's philosophy see Płotka (2020). 
this decision was motivated by the identity of the extensions, but obviously not of the intensions, of the concept of unilaterally inseparable parts and of the concept of unilaterally separable parts: if A and B are unilaterally separable then they are also unilaterally inseparable and vice versa (Ginsberg, 1982, 284, fn. 13). In any case, the list could be completed with the concept of unilateral inseparability.

As an example of mutually separable parts, Twardowski gives the parts of the presentation of a book, i.e., the presentations of the individual pages and cover of a book. On the other hand, mutually inseparable parts are comparable to, for instance, the presentations of a surface and color. Presentations of a genus and of a subordinated species serve as an example of one-sided separability or inseparability: a color is unilaterally separable from redness and redness is unilaterally inseparable from a color (Twardowski, 1977, 61-62).

Concepts of inseparability (Unablösbarkeit) and separability (Ablösbarkeit) were in use in the Brentanian tradition at least since Vom Ursprung sittlicher Erkenntnis (1889), the work which Twardowski refers to. The aforementioned Polish philosopher of course follows in this tradition. Twardowski's immediate source of inspiration was Alois Höfler's Logik. It is worth emphasizing that within the school of Brentano, in a broad sense, the problem of existential conditioning was strictly connected with the problem of the part-whole structure. Existential conditioning was understood as obtaining within a whole or, in other words, dependent objects were always seen as parts of a whole. This is why Twardowski used the terms „unablösbare“ and „abhängig“ interchangeably. It was a general attitude accepted in Brentano's school that the concepts of part and whole "were preferred to the traditional metaphysical notions of genus-species, matter-form, substance-accident, etc. as intuitive, universal and, it seemed likely, clearer than the former ones" (Rosiak, 1998, 85). No wonder that the notion of existential conditioning was also defined in part-whole terms and was thus identified with the concept of inseparability.

Edmund Husserl seems to follow the same path as other students of Brentano. In his Logical Investigations he distinguishes two kinds of parts: pieces and moments. Roughly speaking this distinction corresponds to Twardowski's distinction between physical and metaphysical parts or the much older distinction between concrete and abstract parts. The distinction between pieces and moments can be identified with the distinction between separable and inseparable parts. Inseparability is defined by Husserl as follows:

The sense of inseparability (Unselbständigkeit) lies likewise in the positive thought of dependence (Abhängigkeit). The content is by nature bound to other contents, it cannot be, if other contents are not there together with it. We need not emphasize the fact that 
they form a unity with it, for can there be essential coexistence without connection or "blending," however loose? Contents which lack separability (unselbständige Inhalte) can accordingly only exists as partial contents. (Husserl, 2001, 10) ${ }^{5}$

Inseparable objects are objects belonging to such pure Species as are governed by a law of essence to the effect that they only exist (if at all) as parts of the more inclusive wholes of a certain appropriate Species. This is what we mean by the terser expression that they are parts which only exist as parts that cannot be thought of as existing by themselves. (Husserl, 2001, 12)

As we can see, Husserl identifies both inseparability (Unselbständigkeit) and dependence (Abhängigkeit). Inseparable objects must coexist with other objects and be united with them as parts of a larger whole. Husserl emphasizes that this necessary coexistence within a whole is implied by the essence of an inseparable thing. Moreover, this essence also determines the species of the whole in question. Husserl also introduces a definition of relative inseparability. According to this definition, an object that is a part of whole $\mathrm{A}$ is inseparable from $\mathrm{A}$ if it must coexist, due to its essence, within any whole belonging to the species determined by A or by any part an A (Husserl, 2001, 22). Finally, Husserl defines inseparability not in relation to a more comprehensive whole, but rather to another part (content) (Husserl, 2001, 22).

Another concept that plays a significant role in the Husserlian theory of parts and wholes is the notion of foundation: "If a law of essence means that an A cannot as such exist except in a more comprehensive unity which connects it with an $M$, we say that an $\mathrm{A}$ as such requires foundation by an $\mathrm{M}$ or also that an $\mathrm{A}$ as such needs to be supplemented by an M" (Husserl, 2001, 25). Given the definition of relative inseparability we can say that a foundation implies inseparability, but not vice versa (Rosiak, 1995, 38). For an A is inseparable not only from its foundation in an $\mathrm{M}$ but also from a whole containing M. Yet, such a whole does not have to found an A.

Husserl uses the concept of foundation in his definition of the whole. For him, some contents compose a whole if they are covered by a single foundation. With this subsequently meaning that each content is directly or indirectly connected with all other contents with this connection itself being the foundation (Husserl, 2001, 34). To avoid a vicious circle, Husserl was forced to remove reference to the concept of the whole from the definition of foundation and finally reduced the latter relationship to the necessity of coexistence implied by essence: "A content of the species A is founded upon a content of the species B, if an A can by its essence [...] not exist unless a B also exists" (Husserl, 2001, 34).

5 I revised this translation in accordance with the remarks made in the introduction (see above). 
It is worth remembering that, in his formal ontology, Husserl defines foundation as a formal relationship. Husserl's formal ontology deals with such concepts as "object," "relation," "property," "part," "whole," and so on. Such concepts are devoid of any qualitative content in contrast to material concepts such as "man," "brotherhood," "red," "leg," or "organism." A foundation is not an additional content pressed between two other contents. A foundation is not a regular relation, but is rather a form of direct coexistence (Husserl, 2001, 19-20). In other words, formal relationships, such as a foundation or inseparability are not additional parts of the whole, which is unified by them.

Some of the early critics of Husserl pointed out that his concept of inseparability cannot be applied to all cases of existential conditioning. For example, Ingarden's student - Eugenia Ginsberg-Blaustein (already mentioned) - noticed that relative features existentially condition each other, for example being a wife and being a husband, but they do not make up any whole (Ginsberg, 1982, 273). Unfortunately, Ginsberg-Blaustein did not develop her intuitions because she focused on an immanent criticism of Husserl's theory which intentionally neglected relational features.

\section{ROMAN INGARDEN'S DISTINCTION BETWEEN INSEPARABILITY AND DEPENDENCE: THE CONTEXT OF DISCOVERY}

Ingarden was one of the disciples of Husserl who never accepted the idealistic position of his teacher. Initially, the Polish philosopher attacked the idealism-realism controversy on the grounds of both epistemology and ontology, but later this second perspective became dominant. Ontology was considered by Ingarden as a discipline which investigated the content of ideas (Ingarden, 2013, 61-62). When applied to the realism-idealism controversy, ontology focuses on the content of the idea of the world and on the content of the idea of pure consciousness. One of the results of these investigations was a list of possible relationships between the two mentioned domains. The relationships in question have an existential character in the sense that they are types of possible existential conditionings.

Ingarden formulated the idea that one shall carefully consider the possible relationships between the world and pure consciousness before deciding whether idealism is true, or not, in one of his early letters to Husserl. At the end of July 1918, Ingarden wrote to his teacher:

First of all an ontological question arises: is the essence of reality a separable essence and is it especially an essence separable from the essence of consciousness - as an essence-, or not? Principally spoken, four possibilities are given: 
(1) Reality (as an essence) is inseparable and the essence of consciousness is separable,

i.e. the latter could exist without the essence of reality.

(2) The essence of reality and the essence of consciousness are separable.

(3) The essence of reality is separable. The essence of consciousness is inseparable.

(4) Both are inseparable from each other. (Ingarden, 1976, 435-436) ${ }^{6}$

Here Ingarden seems to use the word "unselbständig" in a looser sense than Husserl. Inseparability is just the necessity of coexistence with something else (in this case with the world or with pure consciousness). However, Ingarden does not mention that these coexistent objects have to compose a whole.

In the paper Bemerkungen zum Problem Idealismus-Realismus, published in 1929, the Polish phenomenologist distinguishes four types of existential conditionings and their opposites, the latter being types of a lack of conditioning:

1. Originality and derivativeness, roughly: $x$ is original iff it is implied by its essence that $x$ cannot be produced nor destroyed; $x$ is derivative iff it is implied by its essence that $x$ is produced by something else (Ingarden, 1929, 165-166).

2. Autonomy and heteronomy, roughly: $x$ is autonomous iff $\mathrm{x}$ has its ontic foundation in itself, i.e. iff all qualities which characterize $x$ are really concretized in $x ; x$ is heteronomous iff $x$ does not have its ontic foundation in itself, especially if all qualities of $x$ are only ascribed to it by another object (i.e. by pure consciousness) (Ingarden, $1929,165)^{7}$.

3. Separability and inseparability: "An object is existentially separable if for its existence it requires no other object which would supplement it within the unity of some whole. In other words, its existence is not a necessary coexistence with some other object within the unity of a whole. In contrast, an object is existentially inseparable if for its existence it requires a coexistence with another [...] object within the unity of a whole" (Ingarden, 1929, 166-167).

$6 \quad$ I have edited the given English translation. For unknown reasons the translator (or the editor) translates "autonomous" and "dependent" as the same word. The original German is as follows: „[...] entsteht zunächst eine ontologische Frage: Ist das Wesen der Realität ein selbständiges Wesen und speziell ein dem Wesen des Bewusstseins gegenüber selbständiges Wesen - als Wesen — oder nicht? Prinzipiell gesprochen liegen 4 Möglichkeiten vor: 1) Realität (als Wesen) unselbständig, das Wesen-Bewusstsein selbständig, d.h. dass es ohne das Wesen Realität existieren konnte. 2) Wesen der Realität und Wesen des Bewusstsein $<$ s $>$ - selbständig. (3) Wesen der Realität selbständig. Bewusstsein unselbständig, 4) Beides unselbständig und aufeinander angewiesen“ (Husserl, 1994, 200).

7 These definitions testify that for Ingarden the term "foundation" had a different meaning than for Husserl. 
4. Independence and dependence: "an object is existentially independent, if it is existentially separable, and does not require for its existence-according to its material essence-the existence of any other separable object. In contrast a separable object is existentially dependent if, despite its existential separability, it requires, according to its essence [...] the existence of another separable object" (Ingarden, 1929, 168).

As we can see, Ingarden follows Husserl's idea that the listed relationships and their opposites are implied by the essences of given objects. This idea was absent in Twardowski's formulations and was what made his concepts closer to the concepts of necessary dependence elaborated upon by contemporary analytical philosophers ${ }^{8}$. According to this approach, $x$ is dependent on $y$ iff it is necessary that $x$ exists only if $y$ exists. The main problem with this formula is that it makes an object dependent on all necessary objects. It is necessary that my dog exists only if trigonometric functions exist because the functions are necessary objects and exist in all possible worlds. Yet we feel that my dog has nothing to do with, for instance, the sine function. To avoid such questionable consequences, it is justified to define dependence and all existential conditionings partially in terms of essence.

The distinguished relationships and their opposites are called existential moments. Some of them are compatible with each other while some are not. For example: independence is incompatible with heteronomy, originality is incompatible with heteronomy, inseparability, and dependence; dependence is by definition incompatible with inseparability. Complexes of compatible existential moments are called ways of being (Ingarden, 2013, 99) . The Ingardenian approach to the realism-idealism controversy consists in the identification of Husserl's modes of givenness with ways of existence. Combinations of the possible ways of existence of pure consciousness with the possible ways of existence of the world are possible solutions to the realism-idealism controversy. In all idealistic solutions, the world is conceived as heteronomous with respect to pure consciousness. In realistic solutions, the world is autonomous (Ingarden, 2013, 167-226). Husserl's alleged transcendental idealism is understood as the position according to which consciousness is original, autonomous, and independent with respect to the world and the world is derivative, heteronomous, separable, and dependent with respect to pure consciousness (Ingarden, 2013, 180-181).

In the context of Ingarden's polemics with Husserl, one can see the first and the main motivation for Ingarden's distinction between inseparability and dependence. Husserl was convinced that the world is constituted, in many stages, by pure con-

8 For the modal approach to dependence see (Tahko \& Lowe, 2016, section 2).

9 For an analysis of ways of being and existential moments see (Chrudzimski, 2015; Mitscherling, 1997; Rosiak, 2007; Simons, 2005). 
sciousness. Ingarden conceived this constitution as a product of the so-called purely intentional object, i.e., an object that possesses only such properties and essence which are ascribed to it by pure consciousness. Thus a constituted object was both derivative and heteronomous with respect to pure consciousness. Yet, for Husserl, the constituted world was transcendent, it did not belong to the sphere of the immanence of pure consciousness. Leaving aside all nuances, we can say that this was one of the differences between Husserl and George Berkeley for whom real objects were bundles of ideas immanent to minds (Ingarden, 1931) ${ }^{10}$. In Ideas I Husserl emphasizes that "It is evident then that intuition and intuited, perception and perceived physical thing, are more particularly, essentially interrelated but, as matter of essential necessity, are not really inherently and essentially one and combined" (Husserl, 1983, 86). The world is somehow essentially connected with the sphere of immanence but is not immersed in it. In Cartesian Meditations ( $\$ 47$ ), Husserl uses the term "immanent transcendence" for this peculiar relationship between a constituted object and pure consciousness (Husserl, 1982, 103-105). The Husserlian concepts of inseparability and foundation, elaborated upon in the Logical Investigations, were not suitable for expressing this type of connection. Ingarden, having his own distinction, would say that for Husserl the world is both separable from and dependent upon pure consciousness.

The distinction between inseparability and dependence was also motivated by the problems of Ingarden's aesthetics. This is unsurprising. Ingarden started to deal with aesthetic issues in strict connection with the realism-idealism controversy. When Ingarden conceived of noemata as intentional objects and when he came to the conclusion that works of art are also intentional objects, his aesthetics was included in an attempt to resolve the problem of idealism. Ingarden refuted psychologism on the grounds of aesthetics. Works of art can "live" longer than the artists who created them and longer than their recipients (readers, listeners, spectators). Hence, works of art cannot be parts of individual conscious acts. Yet they are not physical. An artistic work is one object, although it can have many physical fundaments. Doctor Faustus is one novel, although it can be printed out in many copies. By no means are works of art ideal, they start to exist and can be destroyed. Thus, works of art require conscious acts in order to exist but they are not parts of these acts: "Purely intentional objects are 'transcendent' with respect to corresponding, and in general, to all conscious acts in the sense that no real element (or moment) of the act is an element of the purely intentional object and vice versa. Nevertheless, they belong to the corresponding acts

10 Of course for Berkeley a mind is not pure consciousness. 
from which they draw their source; and they constitute a necessary 'intentional correlate' of acts" (Ingarden, 1973, 118).

Another motivation to introduce the distinction between inseparability and dependence was the Platonism of Ingarden's doctrine. Ingarden accepted Platonism in its ontological form. This means that Ingarden was concerned with only the possibility of ideas and pure ideal qualities and subsequently never decided whether or not they exist ${ }^{11}$. In Essentiale Fragen, an extensive text written earlier than Bemerkungen, Ingarden accepts and creatively develops the main theses of Jean Hering. For Ingarden, all qualities that can be found within individual objects are concretizations of ideal qualities. The particular redness of the slice of the tomato on my sandwich is the concretization of the ideal of redness. Besides ideal qualities we also have ideas. Each idea determines the necessary relationships between the qualities of the object which instantiates an idea. The idea of a square determines that in objects instantiating this idea there coincides particular concretizations of ideal qualities, particularly equilaterality and equiangularity. According to Ingarden, ideal qualities are absolutely transcendent. They are not contained in any particular object nor in ideas. In particular objects and in the contents of ideas we can find only the counterparts of ideal qualities. Nevertheless, the individual counterparts of some ideal qualities are necessarily conditioned by these ideal qualities (Ingarden, 1925, 170-173). In Essentiale Fragen, Ingarden uses the term "unselbständigkeit" but he does not define this term at all. The term "abhängigkeit" also appears in the paper, yet also is undefined and used only in the context of the relation between an object and an act of cognition (Ingarden, 1925, 263). In his later writings, for example in The Controversy over the Existence of the World, Ingarden employs the distinction between inseparability and dependence and thus can say that ideal qualities are totally independent and that their concretizations are separable from ideal qualities but also dependent on these qualities. A similar relationship obtains between individual objects and ideas. The latter are independent of their instances. On the other hand, particular objects are separable from ideas but also are dependent on them ${ }^{12}$.

11 However, on the ground of Ingarden's metaontology we have a problem concerning so-called ontological neutrality. Ingarden claims that ontology is not about factual existence, but characterizes ontology as an "investigation of the contents of ideas." This characterization itself suggests that ideas factually exist.

12 Ingarden's mature theory of the domain of the ideal being is presented in (Ingarden, 2016, 225265). 


\section{INSEPARABILITY AND DEPENDENCE - SOME PROBLEMS OF DEFINITION}

Although the analyzed distinction seems to be very useful it raises some doubts, especially when we consider original Ingardenian formulations. In The Controversy, Ingarden provides his most mature theory of inseparability and dependence, but the definitions given therein are almost the same as those quoted above (Ingarden, 2013, $147,153)$. Ingarden's most controversial formulation is his definition of inseparability. As we could see above, inseparability can be defined as implied by the essence of a given object and the necessity of its coexistence with something else within a whole.

It is quite easy to grasp the idea of inseparability when we take into account the socalled metaphysical parts of objects, for instance properties or the aspects of properties. For instance, a particular roundness is inseparable from a particular ball and we understand this fact very well. A redness in itself is somehow incomplete, it requires some supplementation. The same can be said of a particular brightness of redness. But imagine a whole composed of some complete objects, complete individual subjects characterized by all the properties they should possess. Imagine also that these objects are connected by necessary relations, such relations that are the consequences of the essences of the objects in question. Ingarden (Ingarden, 2016, 350-355) believed that some properties of an object are necessary in the sense that they are implied by the so-called constitutive nature of an object, this being the counterpart of Aristotelian essence. Analogically we can conceive of some necessary relations ${ }^{13}$. A whole composed of some objects united by necessary relations can be named "a strong organic whole." Are the objects which compose a strong organic whole inseparable from each other? If there are no restrictions imposed on the concept of the whole used in the definition of inseparability, we should answer that these objects are inseparable from each other. But previously we admitted these objects are complete and we intuitively feel that even if they stand in some necessary relation to other parts of a strong organic whole, these parts do not supplement each other in the same way as redness supplements a tomato or as brightness supplements a redness. We are apt to think that inseparable objects, metaphorically speaking, permeate each other or are alloyed with each other while dependent objects retain their boundaries although they are necessarily connected. If this is true, then the parts of a strong organic whole are separable despite the fact they compose a whole and must coexist with each other.

13 In fact this analogy is rather weak. According to Ingarden, necessary properties are implied directly by the nature of a thing and do not depend on any external things. This is why Ingarden called these properties unconditionally intrinsic properties. However, necessary relations would be those relations which are implied by the nature of a thing but depend on external things as well. I only wish to emphasize that necessary regular relations are possible. 
I posit that this last statement corresponds to Ingarden's theory. Thus, Ingarden's definition of inseparability should be corrected through the imposition of some restrictions on the concept of the whole. Fortunately, clues concerning the demanded for a correction can be found in Ingarden's writings. This is because Ingarden distinguishes two types of wholes: absolute wholes and summative wholes. Imagine a simple object, an object which lacks proper parts in the sense of Husserlian "pieces" (Stücke). Even if such an object does not have parts it can be called an absolute whole because it "is fully determined in the totality of its material qualification" (Ingarden, 2016, 113). Ingarden adds that this fact results in an "object's all-around unequivocal delimitation and closure" (Ingarden, 2016, 113). Everything which is complete in itself, and does not have to be supplemented, is an absolute whole. Absolute "wholeness" means absolute completeness. Such a whole does not have parts in the regular sense: "the 'whole' in the sense just given can absolutely not be partitioned into individual properties, or moments within these. Also in accordance with the sense of wholeness so understood, nothing can be 'contained' in this 'whole'" (Ingarden, 2016, 113). An absolute whole is just a fully separable object within which some aspects can be distinguished but such that they are fully supplemented by each other. But what is the reason of the separability of an absolute whole and what is the reason for the exhaustive mutual supplementation of the aspects of such a whole? I determine the reason for this is that "in the matters that constitute it [i.e. the object] there is no continuous transition to other objects, and there is also no form that comprehends it and the matter of some other objects, provided it is not a term in a relation or in a higher-level entity" (Ingarden, 2016, 78).

Ingarden also distinguished between material and formal ontology as Husserl did. Ingarden understood formal relationships in the same way as Husserl, as being non-qualitative (content-less) relationships. Some of these relationships obtain between separable objects, for example an instantiation (a relationship between an idea and an individual object) seems to be a formal relationship. On the other hand, some formal relationships obtain between the contents of an object. A complex of such relationships is called the ontological form of an object. The matter of an object is something that is united or organized by an ontological form (Ingarden, 2016, 19-43). The matter of an object is nothing more than all the qualities which can be found within an object. My matter consists of, among other things; my humanity, particular mass, height, intellectual powers and so on. The basic form of an individual object is the subject-properties structure. Thus, being a subject is one formal relationship among many others. Properties perform the function of the characterization of a subject and this function is a formal relationship as well. On the other hand, examples of regular relations include: brotherhood, parenthood, love, hate, being a student, and so on. 
In the above quoted passage from The Controversy (Ingarden, 2016, 78), Ingarden clearly states that an ontological form is the principle of the unity of a separable object. This means that an absolute whole is such a whole whose components are united by some formal relationships. The latter are opposed to regular relations which include some of the content-full ties between objects. Ingarden states that an object is fully complete and separable if none of its qualities are united by a formal relationship within a whole, which contains the qualities of another object. Yet, an object does not lose its separability if it is the term of a regular relation and together with other objects composes a higher-level entity.

"Higher-level entity" is another name for a composed object like a table, a book, or a machine. Such an object is grounded upon, but is not identical to, some whole. It should be noted that such a whole is a whole in another sense, this whole is a summative, or relative, whole: "An entity is a 'whole' in this new sense only with respect to the parts contained in it: it is put together out of them. It is nothing other than the sum of all the parts, and is a 'whole' only relative to these parts and components" (Ingarden, $2016,113)$. Such a whole is not one unit, it is rather the plurality of some objects. The main difference between absolute and summative wholes is that the former are, as we have just seen, united by formal relationships and the latter are something "consisting of relations and resulting from relations" (Ingarden, 2016, 120). This is why summative wholes contain only separable objects.

It is easy to identify that the concept of the absolute whole is entangled in the definition of inseparability. Of course, it is not true that in all cases two or more inseparable objects make up some absolute whole. Yet inseparable entities always make up a whole which is united by a formal relationship. The incompleteness of an inseparable entity consists, among other things, in the necessity of an object being directly supplemented, in being supplemented by such an entity which is not attached to an object due to some additional relative content such as a regular relation. Therefore, only objects which compose a strong organic whole are dependent on each other. Although these objects must coexist due to their essences within some whole, they are separable from each other because the whole in question is a summative whole, it is a whole united by regular necessary relations.

Having this in mind, we can provide updated definitions of inseparability and dependence:

$x$ is inseparable from $y$ iff it is implied by the essence of $x$ that $x$ has to coexist with $y$ within a whole united by a formal relationship(s).

$x$ is dependent on $y$ iff it is implied by the essence of $x$ that $x$ has to coexist with $y$ and that $x$ and $y$ are not components of a whole united by a formal relationship(s). 
Hence, there are three conditions of inseparability, each flowing from the essence of an inseparable object: (i) necessary coexistence with something else, (ii) being a component of some whole and (iii) the formal character of the unity of the whole in question. Thus, a separable object is an object that does not meet at least one of these conditions. In this way we can distinguish three types of separable objects: (i) separable objects, which do not have to coexist with anything else, (ii) separable objects, which have to coexist with something else but do not make up any whole with this other object, (iii) separable objects, which have to coexist with something else and make up a whole with this other object, but this subsequent whole is not united by formal relationships. Objects of the first type are independent while objects of the last two types are dependent.

With the updated definition of dependence, I have omitted the original condition, imposed by Ingarden himself, according to which dependence obtains only between fully separable objects. I think that this condition incorrectly limits the area of possible applications of the concept of dependence. Such a limitation generates problems with the ontological status of some properties, particularly the so-called externally conditioned properties (Ingarden, 2016, 345-348). Consider the shape of a portion of water poured into a glass. The shape is conditioned both by the portion of water and by the internal shape of the glass. Yet we feel these ways of conditioning differ in both cases. Without the distinction between inseparability and dependence we would be unable to express this difference. But with the distinction in mind we can say that the shape of the portion of water is inseparable from the portion itself and dependent on the internal shape of the glass. However, the concept of dependence could not be applied to properties if dependence would obtain only between absolutely separable entities. In fact, we do not need absolute separability in the definition of dependence. The relative separability is enough: if $x$ is dependent on $y$ then $x$ must be separable from $y$. This does not exclude the possibility that $x$ is inseparable from other entities. Analogically, $y$ does not have to be totally inseparable but rather only separable from $x$.

\section{WHAT ARE THE LOGICAL PROPERTIES OF INSEPARABILITY AND DEPENDENCE?}

Ingarden provided a few typologies of inseparability which were elaborated upon through the basis of various criteria (Ingarden, 2016, 148-152):

1. Inseparability comes in different degrees. The inseparability of the brightness of the red color of a tomato is of a higher degree than the inseparability of the color 
red. For the brightness mentioned is inseparable from the redness, the color, and the tomato related to it. The redness thereof is inseparable only from the last two entities.

2. With respect to the range of objects from which a given entity is inseparable Ingarden distinguishes univocal (rigid) and multivocal (generic) inseparability:

\begin{abstract}
Univocal (or univocally relative) inseparability occurs wherever an S, if it is to be able to exist at all as something individual, must be completed into one whole by an $S$ ' that is qualitatively, totally, and unequivocally specified and is therefore unique with respect to this qualitative endowment. In contrast, multivocal (or multivocally relative) inseparability occurs whenever an arbitrary moment from some class containing a plurality of mutually exclusive moments can comprise the completing component of moment $\mathrm{M}$, which simultaneously always requires one of these moments as such a component. (Ingarden, 2016, 149)
\end{abstract}

The updated definition of inseparability given above is in fact a definition of rigid inseparability, of inseparability obtaining with respect to a completely defined (determined) entity. All my properties are univocally (rigidly) inseparable from me. Yet, I am only generically inseparable from my contingent properties. For example, I must have a shape, but not necessarily the one which I have at the moment.

3. With respect to the source of inseparability we can distinguish material and formal inseparability. In the first case, inseparability is caused by the matter of an inseparable object, in the second by an object's ontological form. My particular humanity is materially inseparable from my intellectual powers. Humanity as such is a specific quality, which needs to be supplemented by other specific qualities. On the other hand, my color is formally inseparable from myself. The inseparability of my color is caused not by its qualitative specificity but by the function of characterization that it performs with respect to me.

4. Inseparability can be unilateral (one sided) or reciprocal (mutual). I think this thesis is easily understandable and as such does not require any commentary.

Furthermore, dependence can be rigid or generic, material or formal, mutual or unilateral, and can also come in different degrees. Because existential moments are positive relationships (their opposites - separability and independence - are just lacks of a given conditioning), we can ask questions concerning the logical properties of these moments. We can ask whether they are reflexive, symmetric, or transitive.

It is not clear if whether inseparability is reflexive. Of course no object can exist without itself. But does an object make up a whole with itself? Notice that the word "whole," as used in the definition of inseparability, can also be read as "unity." Inseparable entities are formally united. It seems plausible to say that an object makes up a formal unity with itself. Moreover, this is the strongest unity because it is based on 
a special formal relationship, identity. Thus inseparability is reflexive. The case of the reflexivity of dependence is now clear. A dependent object cannot make up a formal unity with the object upon which it is dependent. Thus dependence is irreflexive.

Obviously, by introducing his explicit distinction between mutual and unilateral inseparability, Ingarden implicitly refutes the thesis that inseparability must always be mutual. Thus, inseparability does not seem to be symmetric nor antisymmetric in the strict logical sense. However, this issue is more intricate. Notice that Ingarden applies the distinction between unilateral and mutual inseparability only to rigid inseparability. Yet such a restriction seems to be too arbitrary. In the example I mentioned above, the inseparability that obtains between a subject and its contingent properties is more complicated. This inseparability is mutual, but in the sense that a subject is generically inseparable from each contingent property and each contingent property is rigidly inseparable from its subject. At first glance, there are three possible cases of mutual inseparability between two entities: (i) rigid in both directions, (ii) generic in both directions, and (iii) rigid in one direction but generic in the other. An example of (i) is a subject and one of its necessary properties: a particular square is rigidly inseparable from a particular equilaterality and vice versa. An example of (iii) has been already given: a subject and its particular contingent property. Two particular contingent properties which characterize one and the same subject can serve as an example of (ii). My skin color must coexist with my body shape but both can change, I can be red and bent or pale and straight. Yet I must have some color and some shape. Hence, these objects are mutually and generically inseparable. These three situations are also purely possible (mutatis mutandis) in the case of dependence.

In this context we can raise another question. Is it necessary that if $x$ is (rigidly or generically) inseparable from $y$, then $y$ is at least generically inseparable from $x$ ? In my opinion, we should answer this question in the positive and perhaps in opposition to Ingarden. As I have said, an inseparable entity is somehow incomplete and makes up a formal unity with another entity. Yet notice that making up a unity seems to be symmetric. If $x$ is united with $y$, then $y$ is united with $x$. Moreover, this is a formal unity. Yet if $y$ would be separable from $x$, then $y$ could be united with $x$ only through a regular relation. This would mean that $y$ makes up a summative whole with $x$ while $x$ makes up a formal unity with $y$. This seems untenable. Thus, I think that the complement of an inseparable entity must be at least generically inseparable from this same entity. It is evident that an analogical statement is not true in the case of dependence, because dependent objects are not formally united with the objects upon which they are dependent. Thus $x$ 's dependence on $y$ is not necessarily associated with $y$ 's rigid or generic dependence on $x$. 
The transitivity of dependence does not raise any doubts. If $x$ is dependent on $y$ and $y$ is dependent on $z$, then $x$ is dependent on $z$. Imagine that a sort of Christian Platonism is true and God creates ideas and sustains them in existence. If this is the case, then individual objects are dependent on ideas and are dependent on God, because ideas also depend on God. The transitivity of inseparability is more controversial although Ingarden presupposes it in his thesis concerning the degrees of inseparability. Is a particular brightness inseparable from a particular tomato, if the brightness is inseparable from a particular redness and the redness is inseparable from the tomato in question? One could say that in this case, the brightness does not make up a direct unity with the tomato and therefore the tomato does not supplement the concerned brightness. Moreover, the whole "brightness + redness" is different from the whole "redness + tomato."

My response to the second objection is the following. In the definition of inseparability, the identity of a whole is not specified. Surely brightness, redness, and the tomato make up one whole that is united by formal relationships. It is then subsequently true that the brightness of the tomato and the tomato itself coexist within such a whole.

The first objection is more problematic. It is true that the brightness and the tomato are not directly united, but are united via redness. Yet notice that redness is not a relation between the brightness and the tomato. The same should be said about the subject of a particular mass and of a particular shape. A subject ties together a mass and a shape not because it is a relation between them, but because a subject is generically inseparable from its properties and these properties are rigidly inseparable from their respective subject. It is still true that the brightness and the tomato or my mass and my shape must coexist within one whole, which is not united by regular relations. The lesson from these considerations is that a relationship of being directly complemented must not be identified with inseparability. Being directly complemented implies inseparability but not vice versa. Nevertheless, inseparability always obtains due to some complementation, but not necessarily due to a complementation obtaining directly between the two inseparable entities in question.

With this, there is one final issue. In the case of the transitivity of inseparability, as understood above, generic inseparability is dominant over rigid inseperability. If $x$ is rigidly inseparable from $y$, and $y$ is generically inseparable from $z$, then $x$ is only generically inseparable from $z$. 


\section{CONCLUDING REMARKS}

Philosophers from the school of Brentano used to define ontological dependence within the context of part-whole theories. Thus, according to the Brentanians, dependencies always obtain between the parts of a whole. Twardowski is a typical representative of this tradition. In his doctrine, different types of dependence are in fact types of a part's inseparability. Husserl is also strongly rooted in this tradition. Yet Ingarden, Husserl's disciple, noticed that such an approach to dependence was too narrow and suggested a more nuanced doctrine of existential moments. One of Ingarden's distinctions, i.e., the distinction between inseparability and dependence, has a more general significance to ontology. Ingarden's motivation to introduce such a distinction was strongly connected with his approach to the problem of idealism, with his aesthetics, and with his theory of ideas. However, this distinction is also applicable beyond these areas. Ingarden's definitions need some clarifications. Ingarden's notion of a whole, which appears in his definition of inseparability, should especially be defined as a formal whole, that is, as a whole based on a formal relationship. Such wholes should be distinguished from summative wholes that are united with regular relations. Inseparability has quite interesting features. It is reflexive (unlike dependence), transitive (in a special sense) and can be mutual. The distinction between inseparability and dependence is a very valuable tool which allows us to express different ontological situations.

\section{REFERENCES}

Chrudzimski, A. (2015). Ingarden on Modes of Being. In B. Leclercq, S. Richard, \& D. Seron (Eds.), Object and Pseudo-Objects: Ontological Deserts and Jungles from Brentano to Carnap (199-222). Berlin: De Gruyter.

Ginsberg, E. (1982). On the Concepts of Existential Dependence and Independence (P. Simons, Trans.). In B. Smith (Ed.), Parts and Moments. Studies in Logic and Formal Ontology (261-287). Munich/ Vienna: Philosophia Verlag.

Husserl, E. (1982). Cartesian Meditations. An Introduction to Phenomenology (D. Cairns, Trans.). The Hague/Boston/London: Martinus Nijhoff.

Husserl, E. (1983). Ideas Pertaining to a Pure Phenomenology and to a Phenomenological Philosophy (F. Kersten, Trans.). The Hague/Boston/London: Martinus Nijhoff.

Husserl, E. (1994). Briefwechsel. Bd. III. Die Göttinger Schule. Husserliana. Dokumente III. Dordrecht/ Boston/London: Kluwer Academic Publishers.

Husserl, E. (2001). Logical Investigations. Vol. 2 (J. N. Findlay, Trans.) (5th ed.). London: Routledge.

Ingarden, R. (1925). Essentiale Fragen. Ein Beitrag zum Wessensproblem. Jahrbuch für Philosophie und phänomenologische Forschung, 7, 125-304.

Ingarden, R. (1929). Bemerkungen zum Problem Idealismus-Realismus. Jahrbuch für Philosophie und phänomenologische Forschung, 11, 159-190. 
Ingarden, R.(1931). Niektóre założenia idealizmu Berkeleya. In Księga Pamiątkowa Polskiego Towarzystwa Filozoficznego (215-258). Lwów: Polskie Towarzystwo Filozoficzne.

Ingarden, R. (1973). The Literary Work of Art. An Investigation on the Borderlines of Ontology, Logic, and Theory of Literature (G. G. Grabowicz, Trans.). Evanston: Northwestern University Press.

Ingarden, R.(1976). The Letter to Husserl about the VI. "[Logical] Investigation" and "Idealism" (H. Girndt, Trans.). Analecta Husserliana, 4, 419-438.

Ingarden, R. (2013). Controversy over the Existence of the World. Vol. I (A. Szylewicz, Trans.). Frankfurt: Peter Lang Edition.

Ingarden, R. (2016). Controversy over the Existence of the World. Vol. II (A. Szylewicz, Trans.). Frankfurt: Peter Lang Edition.

Magdziak, M. (2016) A Logical Analysis of Existential Dependence and Some Other Ontological Concepts. A Comments to Some Ideas of Eugenia Ginsberg-Blaustein. Axioms, 5 (3), 4-10.

Mitscherling, J. (1997). Roman Ingarden's Ontology and Aesthetics. Ottawa: University of Ottawa Press.

Piwowarczyk, M. (2019). Two Models of the Subject-Properties Structure. Axiomathes, 30, 371-390. https://doi.org/10.1007/s10516-019-09463-w

Płotka, W.(2020). Leopold Blaustein’s Descriptive Psychology and Aesthetics in Light of His Criticism of Husserl. In W. Płotka, \& P. Eldridge (Eds.), Early Phenomenology in Central and Eastern Europe: Main Figures, Ideas, and Problems (163-185). Dordrecht: Springer. https://doi. org/10.1007/978-3-030-39623-7_10

Rosiak, M.(1995). Ontologia ufundowania: ogólna teoria części i całości w „Badaniach logicznych“ Edmunda Husserla. Filozofia Nauki, 3 (1-2), 25-61.

Rosiak, M.(1998). Twardowski and Husserl on Wholes and Parts. In K. Kijania-Placek, \& J. Woleński (Eds.), The Lvov-Warsaw School and Contemporary Philosophy (85-100). Dordrecht: Springer.

Rosiak, M. (2007). Existential Analysis in Roman Ingarden's Ontology. Forum Philosophicum, 12 (1), $119-130$.

Simons, P. (2005). Ingarden and the Ontology of Dependence. In A.Chrudzimski (Ed.), Existence, Culture, and Persons: The Ontology of Roman Ingarden (39-53). Frankfurt: Ontos Verlag.

Tahko, T.E., \& Lowe, E. J.(2016). Ontological Dependence. In E. N.Zalta (Ed.), The Stanford Encyclopedia of Philosophy. Retrieved from www.plato.stanford.edu/archives/win2016/entries/dependence-ontological/

Twardowski, K. (1977). On the Content and Object of Presentations (R. Grossmann, Trans.). The Hague: Martinus Nijhoff.

Żegleń, U. (2018). On Existential Dependence and Independence in the World of Thoughts and States of Affairs (with Reference to Eugenia Ginsberg-Blaustein's and Roman Ingarden's Analyses). In A. Garrido, \& U. Wybraniec-Skardowska (Eds.), The Lvov-Warsaw School. Past and Present (249-262). Cham: Birkhäuser. 